\title{
Electrical properties of new polyazomethines
}

\author{
Ekta Sonker $^{1} \cdot$ Rudramani Tiwari $^{1} \cdot$ Krishna Kumar $^{2} \cdot$ S. Krishnamoorthi ${ }^{1}$ (D)
}

Received: 17 March 2020 / Accepted: 15 May 2020 / Published online: 25 May 2020

(c) Springer Nature Switzerland AG 2020

\begin{abstract}
In this study, the synthesis of three novel $\pi$-conjugated Schiff base monomers containing syringaldehyde unit were performed through condensation polymerization technique which is confirmed by NMR and IR spectroscopic techniques. Other characterization i.e. optical properties (fluorescence and UV-Vis), thermal (TG-DTA), electrochemical, Morphological characteristics are performed for the study of application potential of synthesized polymeric materials in organic electronics and voltaic. The resulting polymers were thermally stable up to $270^{\circ} \mathrm{C}$ which is confirmed by TGA analysis. The electrochemical data shows the polymers exhibit low band gaps. Electrical conductivity study indicates that conductivity of polymers is in the range of $\sim 10^{-5} \mathrm{~S} / \mathrm{cm}$ at ordinary temperature. Dielectric study confirms that the capacity of polymers were $0.1-2.8 \mu \mathrm{F}$, permittivity of $\sim 10^{6} \mathrm{~F} / \mathrm{m}$ and $\mathrm{D}$ factor of $>11$.
\end{abstract}

Keywords Polyazomethines · Semiconducting polymers · Thermal analysis · Electrical conductivity · Dielectric properties

\section{Introduction}

Conjugated conductive polymers have attracted great deal of attention during the last two decades because of their highly $\pi$-conjugated polymeric chains and metal like conductivity. Conjugated conducting polymers are widely studied because of their ease of fabrication, suitable nanostructures and remarkable electronic properties like low ionization potential, high electron affinity, low energy optical transitions and electrical conductivity [1]. Conductive polymers are increasingly desired for a growing number of sophisticated end-uses. These polymers are widely used in sensors [2,3], supercapacitor [4], organic photovoltaics $[5,6]$, biofuel cells [7], biomedical engineering [8], drug delivery $[9,10]$, dye sensitized solar cells [11] etc. Currently fluorescent conducting polymers have been developed for various applications such as biological imaging and sensing [12], fluorescent polarizers [13], and light emitting diodes $[14,15]$. They have significantly responded to interaction with number of analytes, including explosives $[16,17]$, metal ions and biological analytes [18], as a result of the fact that the fluorescent sensing probes have distinctive sensing capability.

Conjugated Schiff bases resulting from carbonyl and amino compound are one of the most important categories of organic compounds. The conjugated Schiff bases study has flourished in the last few years because of their wide applications in catalysis, biological modeling, design of molecular magnets $[19,20]$ and in the important drugs synthesis [21]. Schiff bases also plays an essential role as chelating ligands in coordination chemistry because of their easy proton donating property and flexible nature. Furthermore, Schiff base bonds provides suitable features such as; chelating effects to polymers, optoelectronic

Electronic supplementary material The online version of this article (https://doi.org/10.1007/s42452-020-2910-1) contains supplementary material, which is available to authorized users.

S. Krishnamoorthi, dr.skmoorthi@gmail.com | ${ }^{1}$ Department of Chemistry, Centre of Advanced Studies, Institute of Science, Banaras Hindu University, Varanasi 221005, India. ${ }^{2}$ Department of Applied Science, Madan Mohan Malaviya University of Technology, Gorakhpur 273010, India. 
properties, liquid crystal properties, thermal stability and conductivity [22, 23].

Development of $\pi$-Conjugated polyazomethines polymers with conjugative bonds in the main chain has become an area of current research [24]. Major challenges in this field include the development of cheaper, thermally stable, solution-processable, fluorescent and high conducting materials [25]. Entirely aromatic polyazomethines have been recognized as an essential class of highly conjugated and thermally stable materials [26]. Polyazomethines with aromatic backbones are attractive highly efficient conducting polymers because of their good properties like thermal stability, optoelectronic, paramagnetism, fiber-forming, resistance and semiconductivity to high energy $[27,28]$. Conjugated aromatic polyazomethines can be utilized in numerous areas as a result of their semi-conductive properties. Since conjugated polyazomethines have fluorescence characteristics, they may be utilized in the developement of light emitting devices, electrochromic materials and as hole transporting materials in solar cells [29].

In this communication, we have demonstrated the preliminary synthesis of solution processable conjugated polyazomethines based polymers derived from novel synthesized Schiff base monomers containing syringaldehyde unit, through condensation polymerization technique, concomitant with characterization by ${ }^{1} \mathrm{H}-\mathrm{NMR}$ and FT-IR. Thermal stability of the synthesized polymers has been explained by using TG-DTA. Optical absorption properties of the Schiff base monomers and its polymers containing azomethine bond have been studied using UV-Vis spectroscopic technique. Electrochemical behavior of the synthesized compounds has been examined using cyclic voltammetry (CV) technique. Morphological characteristics of the polyazomethines have been explained by SEM device. The electrical conductivity of polyazomethines was studied using impedance analyzer. The resulting aromatic conjugated polyazomethine is expected to exhibit high thermal stability and better semiconducting properties.

\section{Experimental}

\subsection{Materials}

3, 5-dimethoxy-4-hydroxy benzaldehyde (MHB) (99\%, SRL, India), 4-amino benzene sulphonic acid (ABS) (99\%, Merck, India), 2-amino thiophenol (AT) (99\%, Aldrich, Germany), 1,5-diamino naphthalene (AN) (97\%, Aldrich, Germany), p-xylene dibromide (XB) (97\%, Aldrich, Germany) were used as received. Methanol, $\mathrm{N}, \mathrm{N}$-dimethylformamide (DMF) and $\mathrm{Na}_{2} \mathrm{CO}_{3}$ were supplied by SDFCL, Mumbai India.

\subsection{Synthesis of monomers}

Three novel Schiff base monomers were synthesized using condensation reaction between aromatic aldehydes and aromatic amines and they are shown in Scheme 1.

\subsubsection{MHBABS monomer}

In order to synthesis MHBABS monomer, initially in a $250 \mathrm{~mL}$ round bottom flask 4-amino benzene sulfonic acid (ABS) ( $2.25 \mathrm{~g}, 0.013 \mathrm{~mol}$ ) was taken and then it was dissolved in $40 \mathrm{~mL}$ of methanol by continuous stirring on a magnetic stirrer at room temperature. To this, an aldehyde compound, 3, 5-dimethoxy-4-hydroxy benzaldehyde (MHB) $(2.36 \mathrm{~g}, 0.013 \mathrm{~mol})$ solution in $40 \mathrm{~mL}$ of methanol was added dropwise with continuous stirring. After that the reaction mixture was stirred for $10 \mathrm{~min}, 2$ drops of
Scheme 1 Synthesis of MHBABS, MHBAT and MHBAN Schiff base monomer

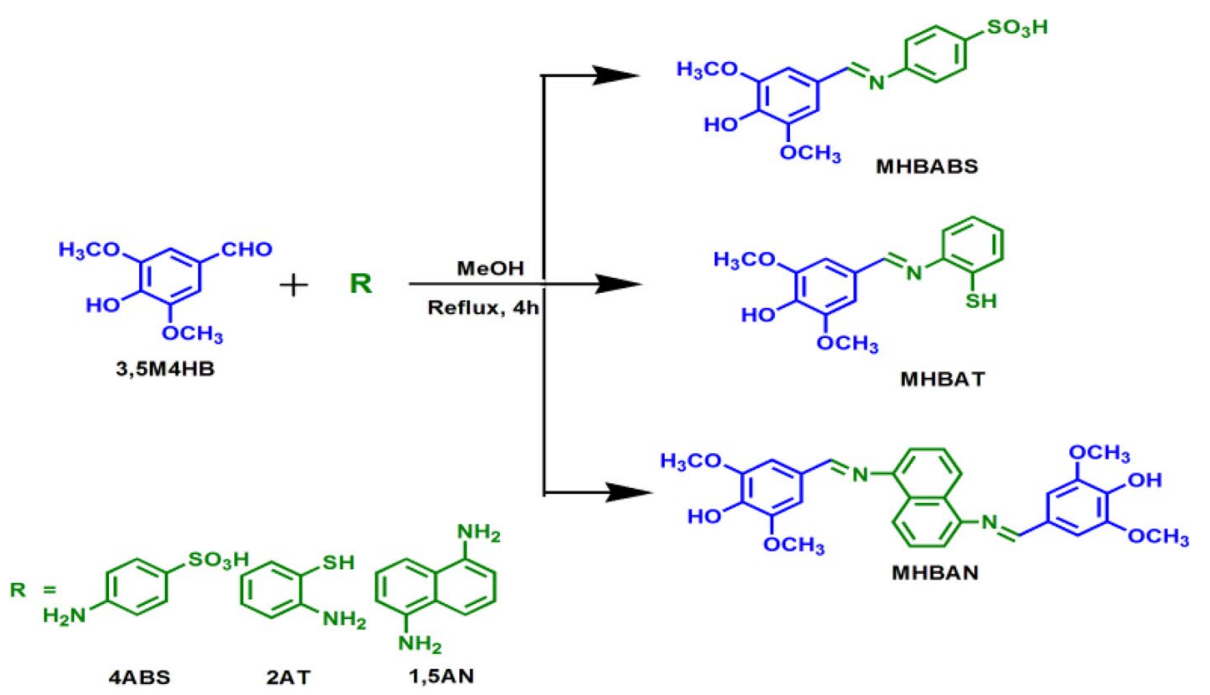


glacial acetic acid were added. Then the mixture was again stirred for $6 \mathrm{~h}$ to form a Schiff base monomer, MHBABS at RT. Finally, the solvent was evaporated to obtain the solid product and then it was washed two times with cold methanol. The precipitated product was crystallized by using acetonitrile. Yield: $90 \%$. ${ }^{1} \mathrm{H}$ NMR (DMSO-d6): $\delta \mathrm{ppm}$, $9.73\left(\mathrm{~s}, 1 \mathrm{H},-\mathrm{SO}_{3} \mathrm{H}\right), 9.13(\mathrm{~s}, 1 \mathrm{H},-\mathrm{OH}), 8.51(\mathrm{~s}, 1 \mathrm{H},-\mathrm{CH}=\mathrm{N})$, 7.60 (d, 2H, Ar-Hc), 7.17 (s, 2H, Ar-Ha), 7.13 (d, 2H, Ar-Hb) and $3.82\left(\mathrm{~s}, 6 \mathrm{H},-\mathrm{OCH}_{3}\right)$.

\subsubsection{MHBAT monomer}

MHBAT monomer was synthesized using a similar procedure to that employed for the synthesis of MHBABS monomer except that 2-amino thiophenol (AT) $(1.63 \mathrm{~g}$, $0.013 \mathrm{~mol}$ ) was used instead of 4 - amino benzene sulfonic acid (4ABS). Yield: 89\%. ${ }^{1} \mathrm{H}$ NMR (DMSO-d6): $\delta$ ppm, 9.24 $(\mathrm{s}, 1 \mathrm{H},-\mathrm{OH}), 8.53(\mathrm{~s}, 1 \mathrm{H},-\mathrm{CH}=\mathrm{N}), 7.50(\mathrm{~d}, 1 \mathrm{H}, \mathrm{Ar}-\mathrm{Hb}), 7.30$ $(\mathrm{s}, 2 \mathrm{H}, \mathrm{Ar}-\mathrm{Ha}), 7.25$ (d, 2H, Ar-Hc), $7.20(\mathrm{t}, 1 \mathrm{H}, \mathrm{Ar}-\mathrm{Hd}), 4.10$ $(\mathrm{s}, 1 \mathrm{H},-\mathrm{SH}), 3.82\left(\mathrm{~s}, 6 \mathrm{H},-\mathrm{OCH}_{3}\right)$.

\subsubsection{MHBAN monomer}

MHBAN monomer was synthesized by using 1, 5-diaminonaphthalene (AN) $(0.95 \mathrm{~g}, 0.06 \mathrm{~mol})$ in the same manner as described above. Yield: $82 \%$. ${ }^{1} \mathrm{H}$ NMR (DMSO-d6): $\delta \mathrm{ppm}$, $9.14(\mathrm{~s}, 2 \mathrm{H},-\mathrm{OH}), 8.51(\mathrm{~s}, 2 \mathrm{H},-\mathrm{CH}=\mathrm{N}), 8.11(\mathrm{~d}, 2 \mathrm{H}, \mathrm{Ar}-\mathrm{Hb})$, $7.49(\mathrm{t}, 2 \mathrm{H}, \mathrm{Ar}-\mathrm{Hc}), 7.55(\mathrm{~s}, 4 \mathrm{H}, \mathrm{Ar}-\mathrm{Ha}), 7.14$ (d, 2H, Ar-Hd) and $3.8\left(\mathrm{~s}, 6 \mathrm{H},-\mathrm{OCH}_{3}\right)$.

\subsection{Synthesis of polyazomethine based polymers}

Three different types of polyazomethine based polymers, P-MHBABSXB, P-MHBATXB and P-MHBANXB containing syringaldehyde unit were synthesized by the action of Schiff base monomers, MHBABS, MHBAT and MHBAN containing different functional groups with aromatic dihalogen compound, $\mathrm{p}$-xylenedibromide (XB) and they are represented in Scheme 2.

\subsubsection{P-MHBABSXB}

The polymerization process was carried out as follows: $3.92 \times 10^{-3} \mathrm{~mol}$ of MHBABS monomer was taken in a $250 \mathrm{~mL}$ of two neck round bottom flask equipped with a condenser and then it was dissolved in $40 \mathrm{~mL}$ of DMF. After that it was refluxed up to $130^{\circ} \mathrm{C}$ under $\mathrm{N}_{2}$ environment followed by the addition of $0.4 \mathrm{~g} \mathrm{Na}_{2} \mathrm{CO}_{3}$ into the flask and again stirred for $30 \mathrm{~min}$. Then $4.2 \times 10^{-3} \mathrm{~mol}$ p-xylenedibromide (XB) was dissolved in $5 \mathrm{~mL}$ of DMF and added dropwise into the flask and the mixture was again refluxed at $130^{\circ} \mathrm{C}$ under a $\mathrm{N}_{2}$ atmosphere for $12 \mathrm{~h}$. At the end of the reaction, a dark black-brown polymer was obtained. After the completion of reaction, the mixture was allowed to cool and precipitated by $250 \mathrm{~mL}$ of water. The synthesized polymer was filtered, washed with water to remove salt and dried in vacuum oven for $24 \mathrm{~h} .{ }^{1} \mathrm{H}$ NMR (DMSO-d6): $\delta$ ppm, $10.13(\mathrm{~s}, 1 \mathrm{H},-\mathrm{CH}=\mathrm{N}), 7.82(\mathrm{~d}, 2 \mathrm{H}, \mathrm{Ar}-\mathrm{Hc}), 7.45-7.10(\mathrm{~m}$, $4 \mathrm{H}, \mathrm{Ar}-\mathrm{Ha}+\mathrm{Ar}-\mathrm{Hb}+\mathrm{Ar}-\mathrm{He}), 5.13(\mathrm{~s}, 2 \mathrm{H}, \mathrm{Hf}), 4.97(\mathrm{~s}, 2 \mathrm{H}, \mathrm{Hd})$ and $3.97\left(\mathrm{~s}, 6 \mathrm{H},-\mathrm{OCH}_{3}\right)$.

\subsubsection{P-MHBATXB}

P-MHBATXB was synthesized using a similar method as described above by using MHBAT monomer $(1.63 \mathrm{~g}$, $0.013 \mathrm{~mol}$ ) instead of MHBABS monomer. ${ }^{1} \mathrm{H}$ NMR (DMSOd6): $\delta$ ppm, $9.97(\mathrm{~s}, 1 \mathrm{H},-\mathrm{CH}=\mathrm{N}), 7.82(\mathrm{~d}, 1 \mathrm{H}, \mathrm{Ar}-\mathrm{Hb}), 7.1-7.8$<smiles>COc1cc(/C=C/Nc2ccc(S(=O)(=O)O)cc2)cc(OC)c1O</smiles>

MHBABS<smiles>COc1cc(/C=N/c2ccccc2S)cc(OC)c1O</smiles>

$$
\mathrm{OCH}_{3}
$$<smiles>COc1cc(/C=N/c2cccc3c(/N=C/c4cc(OC)c(O)c(OC)c4)cccc23)cc(OC)c1O</smiles><smiles>COc1cc(/C=C/N=Cc2ccc(S(=O)(=O)OCc3ccc(C(C)Br)cc3)cc2)cc(OC)c1O</smiles><smiles>COc1cc(/C=N/c2ccccc2SCc2ccc(C(C)(Br)Br)cc2)cc(OC)c1O</smiles>

P. MHBATXB<smiles>COc1cc(N=C=Nc2cccc3c(N=Cc4cc(OC)c(OCc5ccc(CBr)cc5)c(OC)c4)cccc23)cc(O)c1O</smiles>

Scheme 2 Synthesis of P-MHBABSXB, P-MHBATXB and P-MHBANXB polymers 
(m, Ar-Ha $+\mathrm{Ar}-\mathrm{Hc}+\mathrm{Ar}-\mathrm{Hd}+\mathrm{Ar}-\mathrm{Hf}+\mathrm{Ar}-\mathrm{Hg}), 5.09(\mathrm{~s}, 2 \mathrm{H}, \mathrm{Hh})$, 4.97(s, $2 \mathrm{H}, \mathrm{He})$ and $3.99\left(\mathrm{~s}, 6 \mathrm{H},-\mathrm{OCH}_{3}\right)$.

\subsubsection{MHBANXBP}

MHBANXB was also synthesized by using MHBAN monomer $(0.95 \mathrm{~g}, 0.06 \mathrm{~mol})$ in the same manner. ${ }^{1} \mathrm{H}$ NMR (DMSOd6): $\delta \mathrm{ppm}, 9.93(\mathrm{~s}, 2 \mathrm{H},-\mathrm{CH}=\mathrm{N}), 8.11(\mathrm{~d}, 2 \mathrm{H}, \mathrm{Ar}-\mathrm{Hb}), 7.9-7.1$ $(\mathrm{m}, 2 \mathrm{H}, \mathrm{Ar}-\mathrm{Hc}+\mathrm{Ar}-\mathrm{Ha}+\mathrm{Ar}-\mathrm{Hd}+\mathrm{Ar}-\mathrm{Hf}), 5.33(\mathrm{~s}, 2 \mathrm{H}, \mathrm{He})$ and $3.8\left(\mathrm{~s}, 6 \mathrm{H},-\mathrm{OCH}_{3}\right)$.

\subsection{Measurements}

The solubility behavior of all the synthesized polyazomethines were tested qualitatively in a variety of solvents. It was found that all the polymers were insoluble in common organic solvents like acetone, $\mathrm{CHCl}_{3}$, THF and DCM. These synthesized polyazomethines were soluble in polar aprotic solvents such as DMF, DMAc, NMP, DMSO and pyridine. FT-NMR spectrometer (JEOL AL 500) was used to record the ${ }^{1} \mathrm{H}$ NMR spectra by using DMSO-d6 as a solvent and tetramethylsilane (TMS) as an internal reference. IR spectra were acquired on Thermo Nicolet FT-IR spectrometer (Perkin-Elmer FT-IR spectrum two) within the range of $400-4000 \mathrm{~cm}^{-1}$ by using $\mathrm{KBr}$ pellets. Thermal analysis was performed by TGA-DTA analyzer (Perkin-Elmer STA 6000) with a heating rate of $10^{\circ} \mathrm{C}$ per minute under $\mathrm{N}_{2}$ atmosphere. The sample analysis was carried out from 30 to $800^{\circ} \mathrm{C}$. The weight loss was recorded as a function of temperature. The number average molar weight $\left(M_{n}\right)$, weight average molar weight $\left(M_{w}\right)$, and polydispersity index $\left(M_{w} / M_{n}\right)$ of P-MHBABSXB, P-MHBATXB, P-MHBANXB were measured by Youglin ACME 9000 GPC in DMF with a flow rate of $0.5 \mathrm{~mL}$ per minute at $40{ }^{\circ} \mathrm{C}$ on two polystyrene gel columns connected to a Younglin ACME 9000 RI detector and a Younglin ACME 9000 Gradient Pump. Ultraviolet-visible absorption spectra were recorded in DMSO by UV-Vis spectrophotometer (UV-1700 Pharma spec) at $25^{\circ} \mathrm{C}$. Cyclic voltammetry measurements were performed with a bipotentiostat (AFRDE 4E, Pine Instruments) together with an e-corder (201, eDAQ) at $80 \mathrm{mV} / \mathrm{s}$ scan rate under argon. Polymers were dissolved in dry DMSO at $10^{-3} \mathrm{M}$ containing $0.1 \mathrm{MTBAPF}_{6}$. A saturated Ag/ $\mathrm{AgCl}$ electrode was employed as a reference electrode and a platinum electrode as an auxiliary electrode. Fluorescence measurements were performed on Varian Cary Eclipse fluorescence spectrometer in DMSO. Concentration of the compounds was $0.01 \mathrm{mg} / \mathrm{mL}$ and slit width was $5 \mathrm{~nm}$. SEM images of the polymers were captured by an HRSEM Supra 40, Zeiss instrument. Wayne Karr impedance analyzer model 6500B made by Wayne Karr instrument used to determine impedance of sample film, data were recorded in the frequency range $20 \mathrm{~Hz}-10 \mathrm{MHz}$ with applying potential of $100 \mathrm{mV}$. The temperature dependent impedance measurements were carried out by placing the polymeric samples between two stainless steel blocking electrodes inbuilt in sample holder and then the entire assembly was placed in furnace in the temperature range $30-100^{\circ} \mathrm{C}$ with the accuracy of $\pm 1{ }^{\circ} \mathrm{C}$. Altas constant thickness film maker model GS15810 made up by Specac limited UK was used for making polymer film with constant thickness. Instrument has specific dies ring for making specific thickness film, temperature set up (room temperature to $500^{\circ} \mathrm{C}$ ) and pressure control ( 0 to 15 tons). Whole set up shows accuracy of $\pm 1 \%$.

\subsection{Sample preparation for conductivity measurement}

Initially $100 \mathrm{mg}$ of polymer was taken in aluminium cup and covered by aluminium foil cap. Than it was placed inside film maker, and temperature was set at $100^{\circ} \mathrm{C}$. When temperature reached to $100^{\circ} \mathrm{C}, 2$ ton pressure was applied for $1 \mathrm{~min}$. After that the polymeric film was cooled at room temperature. Film with aluminium foil was taken out from film maker and finally aluminium foil was separated out from the surface of polymeric film. Now polymeric film was ready for analysis of its electrical properties.

Doping of polymeric film was done by exposure of the thin film to iodine vapour for $6 \mathrm{~h}$ in desiccator. Then the film was taken out from the chamber and allowed to stabilize in open environment for $1 \mathrm{~h}$. Doped polymeric film was ready for study of its electrical properties.

\section{Results and discussion}

\subsection{NMR spectroscopy}

${ }^{1} \mathrm{H}$ NMR spectra of all the monomers and their polymers are given in Figure S1 (a) and (b). NMR spectra of monomers give sharp peaks as estimated. The hydroxyl, aromatic and azomethine proton peaks were observed at 9.2, 8.2-7.1 and $8.5 \mathrm{ppm}$ respectively. In ${ }^{1} \mathrm{H}$ NMR spectra of polymers, an enlargement of the peaks and an enhancement in the number of the peaks were examined. This peaks enlargement was appeared because of the presence of repetitive monomer units having different chemical environments. ${ }^{1} \mathrm{H}$ NMR spectroscopic data showed the disappearance of thiol peak of thiophenol, hydroxyl peak of syringaldehyde and hydroxyl peak of sulphonic acid groups in the polymers that confirmed the formation of polymer with sulfonate ester, thioetheric and the etheric bridge. 


\subsection{Infrared spectroscopy}

Figure S2 (a) and (b) gives the FT-IR spectra of the synthesized monomers and their polymers. The major FT-IR absorption bands observed in monomer and corresponding polymers, their assignments, and data are listed in Table 1. In the IR spectra (Figure S2 a), for MHBABS, MHBAT, and MHBAN, $-\mathrm{OH}$ peak was observed at 3515,3422 and $3485 \mathrm{~cm}^{-1}$ respectively and the conversion of $\mathrm{NH}_{2}$ (amine) into $\mathrm{N}=\mathrm{CH}$ (imine) by condensation was observed at 1659,1623 and $1620 \mathrm{~cm}^{-1}$ respectively. The appearance of $\mathrm{HC}=\mathrm{N}$ stretching frequency along with imine $-\mathrm{CH}$ stretching frequency and the methoxy stretching frequency confirmed the formation of the monomers. In the IR Spectra (Figure S2 b), for P-MHBABSXB, P-MHBATXB and P-MHBANXB, $-\mathrm{C}-\mathrm{OH}$ peak of phenylene group was observed at 1209,1273 and $1208 \mathrm{~cm}^{-1}$ respectively. This proved that hydroxyl peak of the monomers at $3400-3500 \mathrm{~cm}-{ }^{1}$ disappeared in consequence of polymer formation. In the IR spectrum of $\mathrm{P}-\mathrm{MHBABSXB},-\mathrm{S}=\mathrm{O}$ peak of sulfonate ester was seen at $1358 \mathrm{~cm}^{-1}$. In IR spectra of polymers, an enlargement of the peak was because of the presence of repetitive monomer units. It was also observed that the $\mathrm{N}=\mathrm{CH}$ bond in monomers shifted to lower wave number in polymers.

\subsection{Thermal analysis}

Thermal degradation patterns of the synthesized polymers have been displayed in Fig. 1a. Thermal degradation values for the polymers are given in Table 2. From the degradation pattern it is obvious that all the polymers follow a four-stage decomposition pattern. The initial weight loss, beginning from $\mathrm{RT}$ to $150.0^{\circ} \mathrm{C}$ corresponded to removal of water molecules present in the polymer backbone. The second stage loss at around $270.0^{\circ} \mathrm{C}$ is associated with a loss of ether, thioether and sulfonate ester linkage from the P-MHBABSXB, P-MHBATXB and P-MHBANXB, respectively. These weak bonds are easily broken at reasonable temperatures and make them thermally unstable. The third stage weight loss at around $360^{\circ} \mathrm{C}$ corresponded to the elimination of imine group from the polymers backbone. Finally, the weight loss after $600.0^{\circ} \mathrm{C}$ is observed due to decomposition and degradation of the polymer. In thermal analysis of all the polymers synthesized by condensation polymerization technique, the weight loss
Table 1 FT-IR spectral data of Schiff base monomers and polyazomethines

\begin{tabular}{llllll}
\hline Compounds & $\begin{array}{l}\text { Imine } \mathrm{CH}=\mathrm{N} \\
\left(\mathrm{cm}^{-1}\right)\end{array}$ & $\begin{array}{l}\text { Aromatic } \\
\mathrm{C}-\mathrm{H}\left(\mathrm{cm}^{-1}\right)\end{array}$ & Aliphatic $\mathrm{C}-\mathrm{H}\left(\mathrm{cm}^{-1}\right)$ & $-\mathrm{OH}\left(\mathrm{cm}^{-1}\right)$ & $\mathrm{C}-\mathrm{O}-\mathrm{C}\left(\mathrm{cm}^{-1}\right)$ \\
\hline MHBABS & 1659 & 3058 & 2995,2853 & 3515 & 1119 \\
MHBAT & 1623 & 3055 & $2995,2939,2840$ & 3422 & 1114 \\
MHBAN & 1620 & 3074 & 2934,2855 & 3485 & 1118 \\
P-MHBABSXB & 1597 & 3025 & 2925,2850 & - & 1121 \\
P-MHBATXB & 1605 & 3063 & 2925,2854 & - & 1110 \\
P-MHBANXB & 1605 & 3060 & 2926,2857 & - & 1121 \\
\hline
\end{tabular}

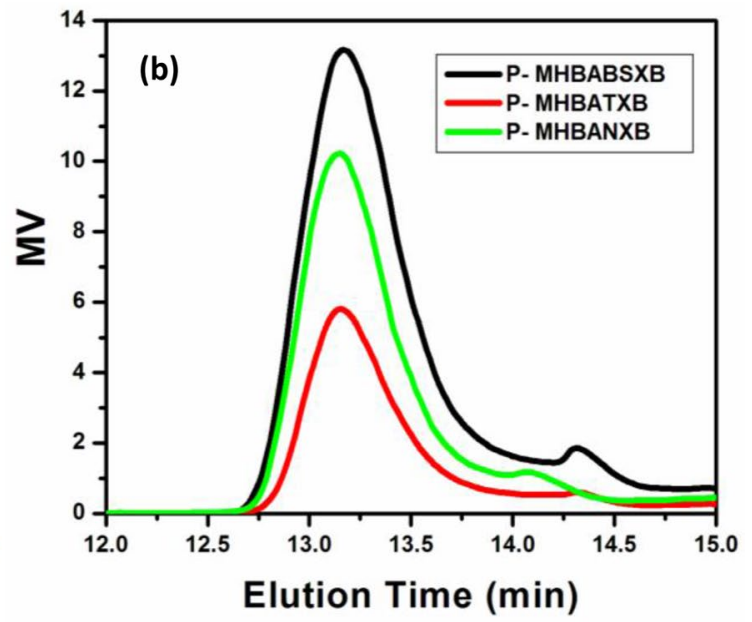

Fig. 1 a TGA of the polyazomethines. b GPC chromatograms of the polyazomethines 
Table 2 Molecular weights and thermal degradation values of polyazomethines

\begin{tabular}{lllllll}
\hline Polymer & Mn & Mw & PDI & $\begin{array}{l}\text { Temp. at 20\% } \\
\text { weight loss }\left({ }^{\circ} \mathrm{C}\right)\end{array}$ & $\begin{array}{l}\text { Temp. at 50\% } \\
\text { weight loss }\left({ }^{\circ} \mathrm{C}\right)\end{array}$ & $\begin{array}{l}\% \text { Char } \\
\text { at } 800 \\
{ }^{\circ} \mathrm{C}\end{array}$ \\
\hline P-MHBABSXB & 32,849 & 76,421 & 2.32 & 365 & 679 & 41 \\
P-MHBATXB & 33,613 & 70,903 & 2.37 & 383 & 772 & 48 \\
P-MHBANXB & 59,190 & 15,8191 & 2.67 & 381 & 574 & 24 \\
\hline
\end{tabular}

patterns are similar but the \% of weight loss is dissimilar. From this study, it is observed that the synthesized polymers are thermally more stable.

\subsection{GPC analysis}

The polymer samples were subjected to GPC analysis and the results support polymer formation with a fairly high polydispersity index (PDI). The GPC (Fig. 1b) spectrum gives the molecular weight with polymerization time. The average molecular weight of polymers is shown in Table 2. According to this, the number of repeated monomer units in P-MHBABSXB, P-MHBATXB, P-MHBANXB are 126, 127 and 210 respectively.

\subsection{Optical properties}

The UV-Visible absorption spectra are valuable to recognize extent of conjugation in conducting polymers. In The UV spectrum given in Fig. 2a, two types of absorption peak were observed. The absorption peaks of $n \rightarrow \pi^{*}$ transition of the azomethine groups and $\pi \rightarrow \pi^{*}$ transitions of the aromatic ring were observed in all the synthesized monomers and their polymers. In monomers,
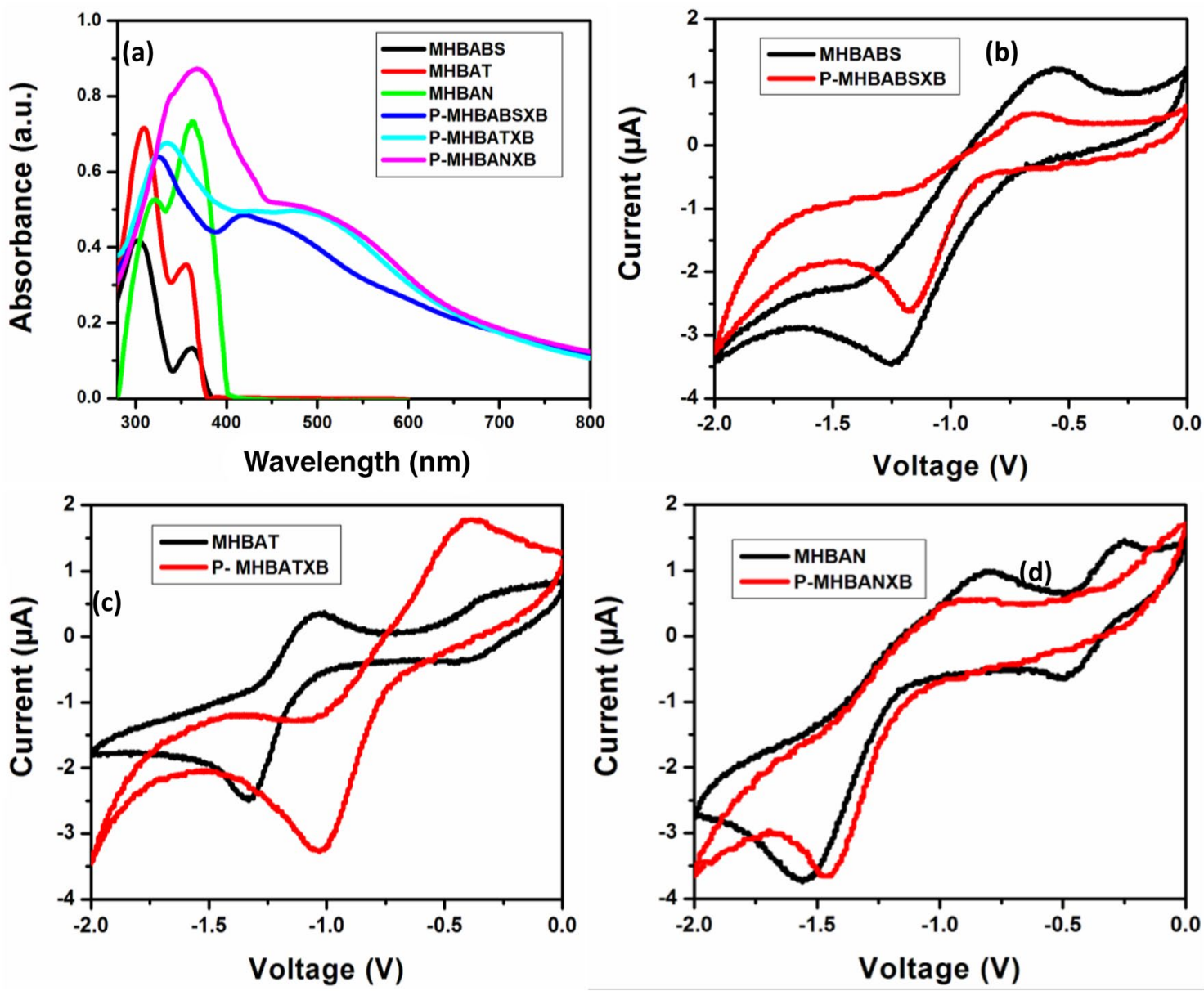

Fig. 2 Absorption spectra and cyclic voltammograms of Schiff base monomers and polyazomethines 
these peaks were observed at lower wavelength whereas in polymer, it is evident that these peaks shifted to the right due to increase in degree of conjugation. For MHBABS, MHBAT, MHBAN, P-MHBABSXB, P-MHBATXB and P-MHBANXB $n \rightarrow \pi^{*}$ electronic transitions were observed at $363,355,360,420,485$, and $470 \mathrm{~nm}$ respectively and $\pi \rightarrow \pi^{*}$ electronic transitions were observed at $300,310,320,325,335$ and $365 \mathrm{~nm}$ respectively. The enhance degree of conjugation in polymers was confirmed by their absorbance spectra that are shifted bathochromically relative to their monomers. This is due to enhance degree of conjugation present in the polyazomethines.

\subsection{Electrochemical properties}

Cyclic voltammetry technique is used to study the electrochemical characteristics of the monomers and their polymers. The current-potential voltammograms of all the monomers and their corresponding polymers are given in Fig. $2 b-d$ as coincident. All the Schiff base monomers and their polymers possessed both oxidation and reduction peaks, confirming their $p$ - and n-type behavior. The HOMO-LUMO energy levels as well as the electrochemical band gaps $\left(E^{\prime} g\right)$ were measured from the oxidation-reduction onset values according to known methods [30]. Electrochemical values of all the compounds are shown in Table 3. The large redox potentials calculated further confirmed the strength of the synthesized compounds. On the other hand, a less positive oxidation potential was observed for polymers represents its significant degree of conjugation. From the electrochemical data, it was confirmed that the polymers possesses smaller electrochemical band gaps than their monomers. The smaller band gap accelerates electronic transitions among HOMO-LUMO energy levels. Hence, the polymers become highly electrical conductive as compared to their monomers.

Table 3 Optoelectronic structure parameters of Schiff base monomers and polyazomethines

\begin{tabular}{llllll}
\hline Compounds & $\mathrm{E}_{\mathrm{ox}}(\mathrm{eV})$ & $\mathrm{E}_{\mathrm{red}}(\mathrm{eV})$ & $\mathrm{HOMO}(\mathrm{eV})$ & $\mathrm{LUMO}(\mathrm{eV})$ & $\mathrm{E}^{\prime} \mathrm{g}(\mathrm{eV})$ \\
\hline MHBABS & 1.324 & -0.827 & -5.974 & -3.823 & 2.151 \\
$\begin{array}{l}\text { P-MHBAB- } \\
\quad 1.151\end{array}$ & -0.914 & -5.801 & -3.736 & 2.065 \\
$\quad$ SXB & & & & & \\
MHBAT & 1.091 & -1.293 & -5.741 & -3.357 & 2.384 \\
P-MHBATXB & 0.994 & -0.761 & -5.644 & -3.889 & 1.755 \\
MHBAN & 1.429 & -1.184 & -6.079 & -3.466 & 2.613 \\
P-MHBANXB & 1.1803 & -1.421 & -5.830 & -3.229 & 2.601 \\
\hline
\end{tabular}

\subsection{Fluorescence measurements}

The conjugated polymers emit light of different intensities at different wavelengths by showing fluorescence properties. When a substance emitted light in visible region, then the substance is appears to exhibit visible colored emission. Fluorescence spectra of the Schiff base monomers and their polymers are given in Fig. 3. From the Figure, it is observed that the emission spectra of all the polymers are shifted bathochromically comparative to those measured for their monomers. This is comparatively due to a greater degree of conjugation associated with electronic effects resulting from the electron withdrawing azomethine groups.

\subsection{SEM analysis}

Morphological characteristics of the polymers were explained by SEM device. P-MHBABSXB, P-MHBATXB and P-MHBANXB were used in the form of powder. The SEM image has scan under $10 \mathrm{KX}$ magnifications. Figure $4 a-c$ shows the SEM images of P-MHBABSXB, P-MHBATXB and $P-M H B A N X B$, respectively. The surface morphology of P-MHBABSXB was a non-uniform round shaped structure which was altered to a different shape and size $(0.5$ to $0.6 \mu \mathrm{m}$ ). P-MHBATXB showed uniform block morphology having different size varying from 02 to $20 \mu \mathrm{m}$. SEM image of P-MHBANXB showed globular structure having rough surface and varying the size from 0.2 to $20 \mu \mathrm{m}$.

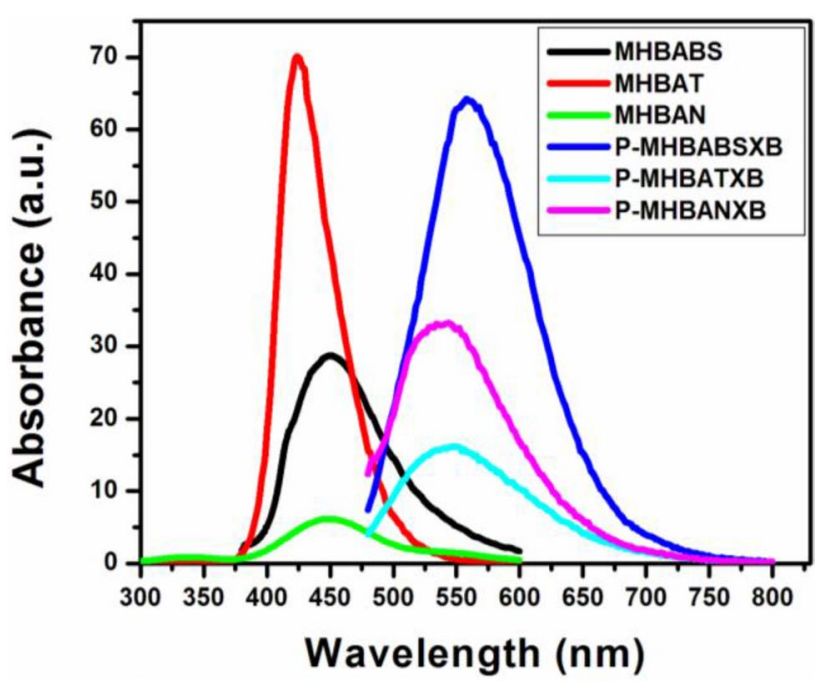

Fig. 3 Fluorescence spectra of Schiff base monomers and polyazomethines 

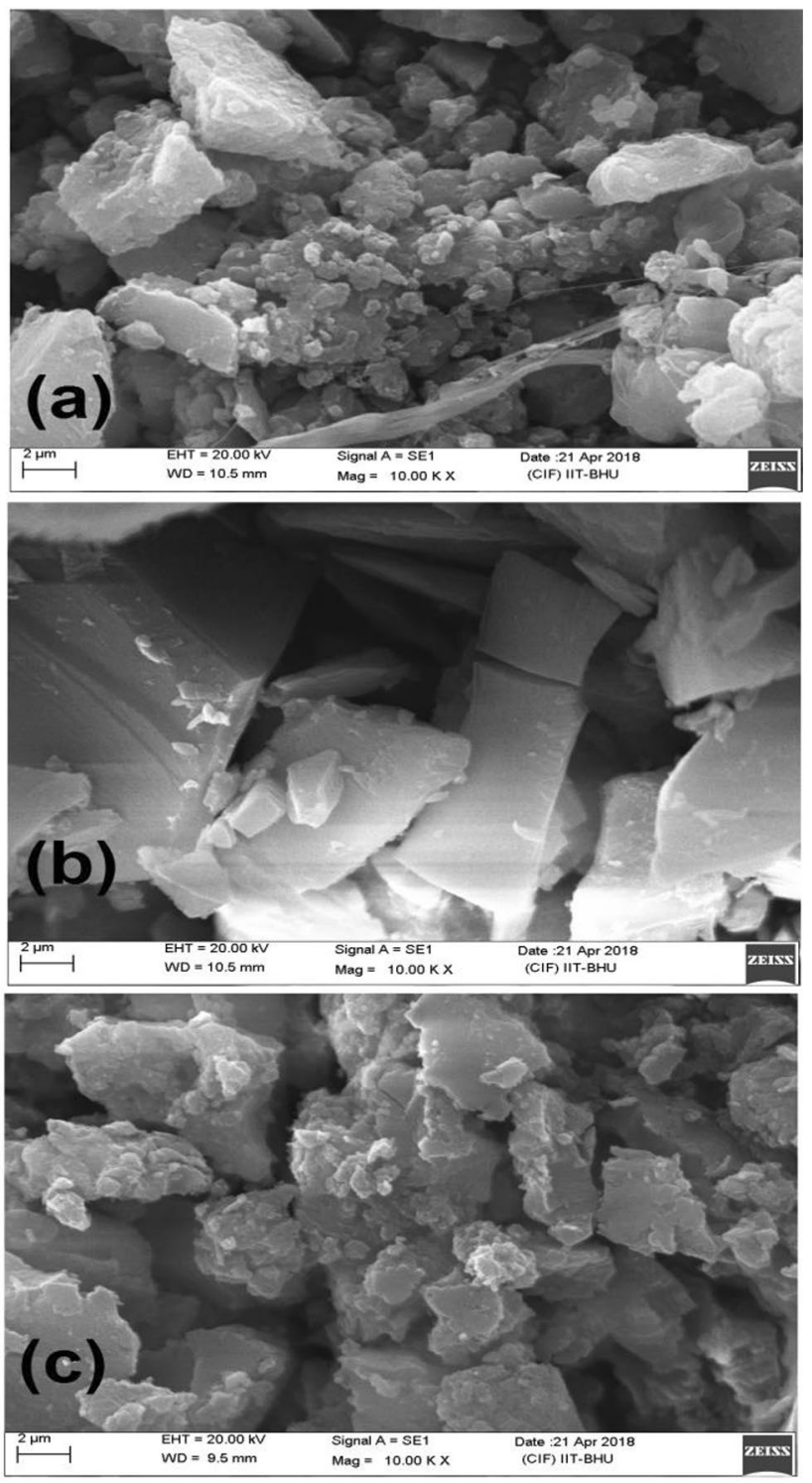

Fig. 4 SEM photographs of a P-MHBABSXB, b P-MHBATXB and $\mathbf{c}$ P-MHBANXB

\subsection{Study of electrical conductivity}

Figure 5 shows the Nyquist plots ( $Z^{\prime}$ vs. $Z^{\prime \prime}$ ) of three different polymeric films at different temperatures. The DC conductivity is determined from the semi-circular arc intercept on real part of impedance $Z^{\prime}$ axis (i.e. bulk resistance, $R_{b}$ ) by using relation:

$\sigma_{\mathrm{dc}}=\left(1 / \mathrm{R}_{\mathrm{b}}\right) \times(\mathrm{I} / \mathrm{A})$

where $l=$ thickness of the sample film in $\mathrm{cm}, A=$ area of the sample holder in $\mathrm{cm}^{2}$ and $\mathrm{R}_{\mathrm{b}}=$ bulk resistance.

The DC conductivity of P-MHBABSXB, P-MHBATXB and P-MHBANXB was found out of range at without doping condition, However, $\mathrm{I}_{2}$ doped films of P-MHBABSXB, P-MHBATXB and P-MHBANXB showed higher DC conductivity $4.22 \times 10^{-5} \mathrm{~S} / \mathrm{cm}, 4.23 \times 10^{-5} \mathrm{~S} / \mathrm{cm}$, and $1.02 \times 10^{-5} \mathrm{~S} / \mathrm{cm}$ respectively at $30^{\circ} \mathrm{C}$. This was due to the oxidation of $\mathrm{I}_{2}$ and enhanced amorphousness of polymeric film matrix. The DC conductivity increased up to $10^{-4} \mathrm{~S} / \mathrm{cm}$ for all polymers at high temperature $\left(100^{\circ} \mathrm{C}\right)$ due to increase in chain flexibility at higher temperature.

The temperature reliant $D C$ conductivity of $I_{2}$ doped polymeric films shows the thermally activated process which is basically Arrhenius type (log $\sigma_{d c}$ vs $1000 / T$ given in Fig. 5) given as:

$\sigma_{\mathrm{T}}=\sigma_{0} \exp ^{-\mathrm{Ea} / \mathrm{kT}}$

where $\mathrm{E}_{\mathrm{a}}=$ activation energy $(\mathrm{eV}), \mathrm{k}=$ Boltzmann constant, $\mathrm{T}=$ temperature $(\mathrm{K})$ and $\sigma_{0}$ is the pre-exponential factor. Figure 5 reveals that the DC conductivity varies linearly as the temperature increases and follows the Arrhenius type thermally activated process with phase transition. The values of activation energy for P-MHBABSXB, P-MHBATXB and P-MHBANXB are $0.15 \mathrm{eV}, 0.23 \mathrm{eV}$ and $0.09 \mathrm{eV}$ respectively before transition and $0.08 \mathrm{eV}, 0.24 \mathrm{eV}$ and $0.05 \mathrm{eV}$ respectively after transition.

The frequency dependent conductivity study shows increase in conductivity with increasing frequency and shifting of the middle region towards higher conductance value in $\sigma_{a c}(\mathrm{~S} / \mathrm{cm})$ versus $\log \mathrm{f}(\mathrm{Hz})$ plots with different temperatures (Figure S3) for P-MHBABSXB, P-MHBATXB and $P$-MHBANXB polymers. It indicates that the ion dynamics is thermally activated. $\sigma_{\mathrm{ac}}(\mathrm{S} / \mathrm{cm})$ versus $\log \mathrm{f}(\mathrm{Hz})$ plots are probable to follow the Jonscher's Power law (JPL) which is given by

$\sigma=\sigma_{\mathrm{dc}}+\mathrm{Af}^{\mathrm{n}}$

where $\sigma_{d c} D C$ conductivity of film, $A=$ constant, $n=$ power exponent.

In AC conductivity spectra of P-MHBABSXB, P-MHBATXB and P-MHBANXB polymer are shown in Fig. $6 \mathrm{a}$. The value of power exponent is $n<1$ for all 3 polymers $(n \sim 0.87, n \sim 0.47$ and $\mathrm{n} \sim 0.14$ for P-MHBABSXB, P-MHBATXB and P-MHBANXB respectively) reveals the possible mechanism i.e. free hopping to correlated hopping type because of increased number of charge carries. [31, 32] Study of dielectric relaxation properties of polymer also performed to study the transport behavior and the polarization effect in polymeric film (Table 4). The loss tangent (ratio of loss factor $\left(\varepsilon^{\prime \prime}\right)$ to dielectric constant $\left(\varepsilon^{\prime}\right)$, represented by $\tan \delta$ ) is calculated by applying relation;

$\tan \delta=\frac{\varepsilon^{\prime \prime}}{\varepsilon^{\prime}}$ 

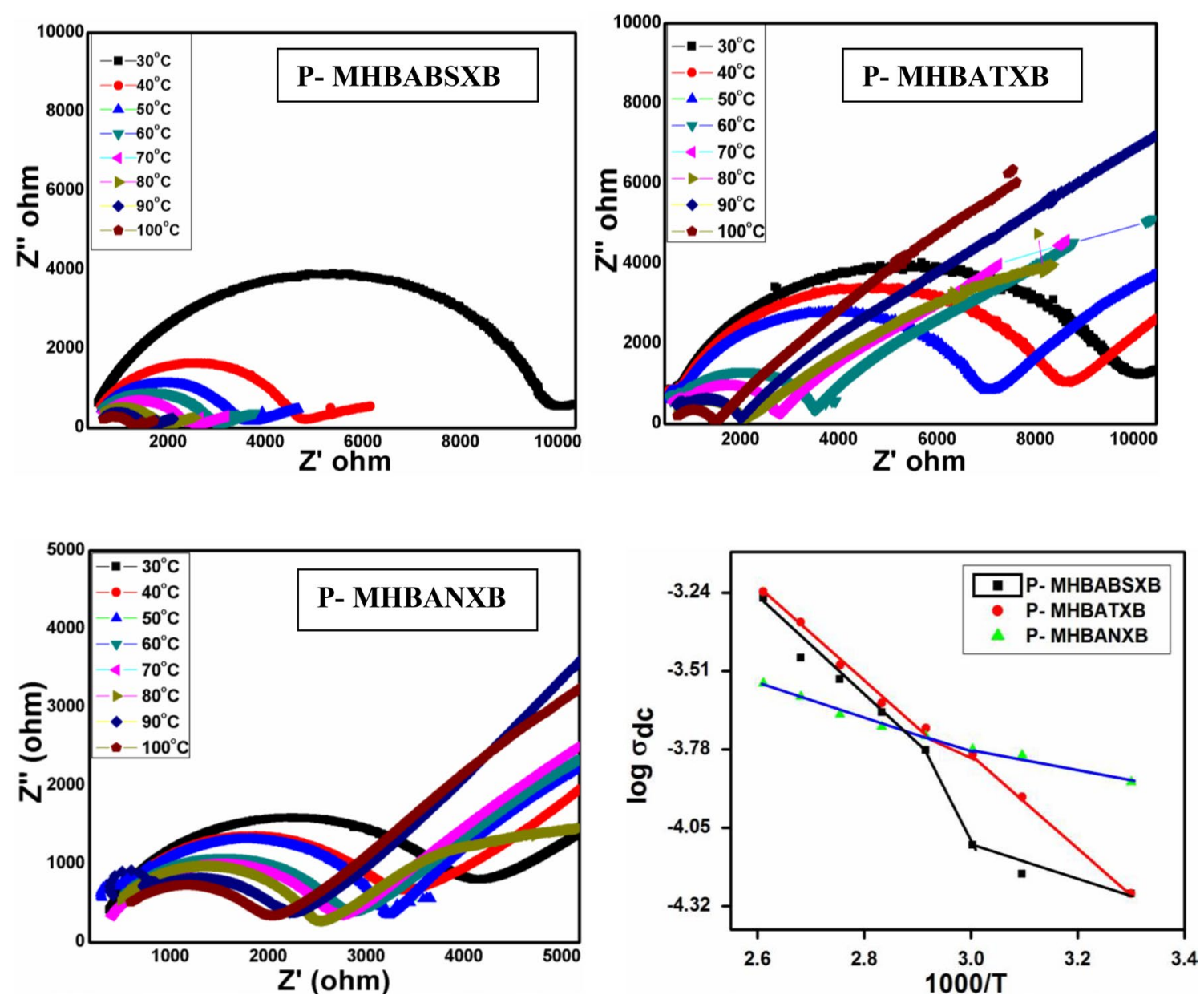

Fig. 5 Typical Nyquist plot of polyazomethines at different temperature and $\log \sigma_{\mathrm{dc}}$ versus 1000/T plot for polyazomethines
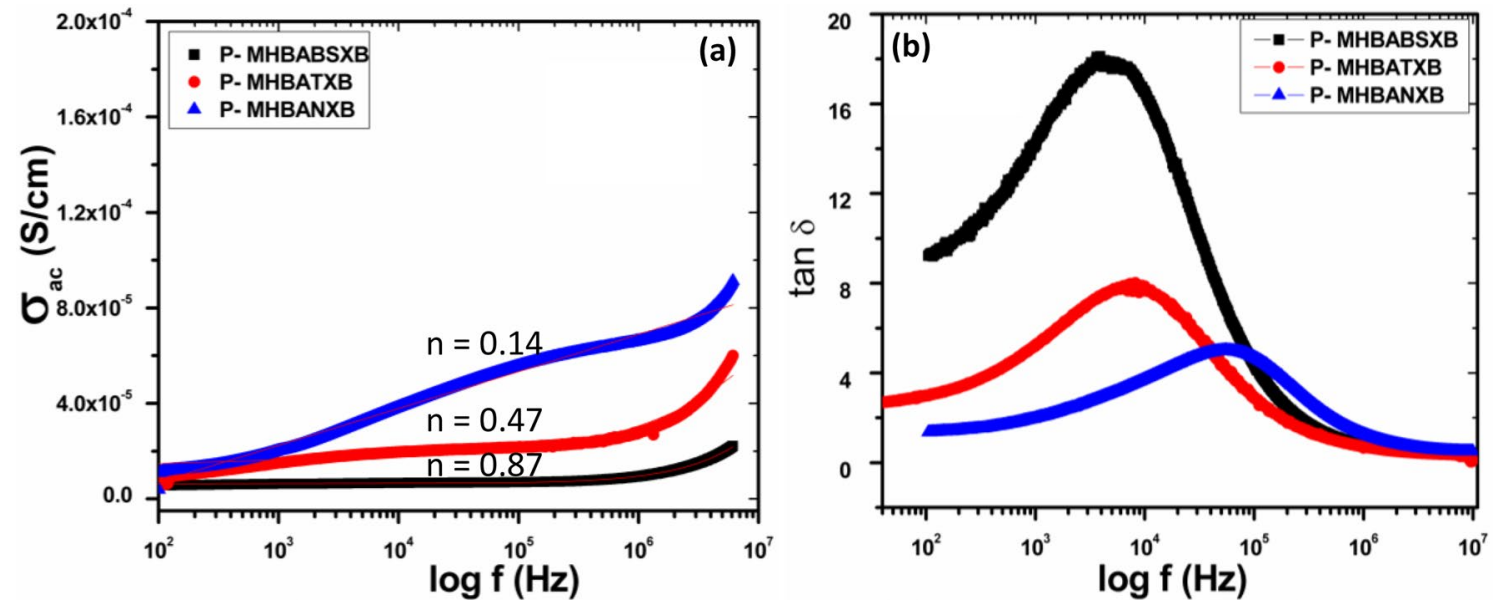

Fig. 6 a $A C$ conductivity spectra of P-MHBABSXB, P-MHBATXB and P-MHBANXB polymers at $30{ }^{\circ} \mathrm{C}$ (curves are fitted using relation $\sigma=\sigma_{\mathrm{o}}+A f^{n)}$. b Loss tangent $(\tan \delta)$ versus $\log \mathrm{f}(\mathrm{Hz})$ plot for P-MHBABSXB, P-MHBATXB and P-MHBANXB at $30^{\circ} \mathrm{C}$ 

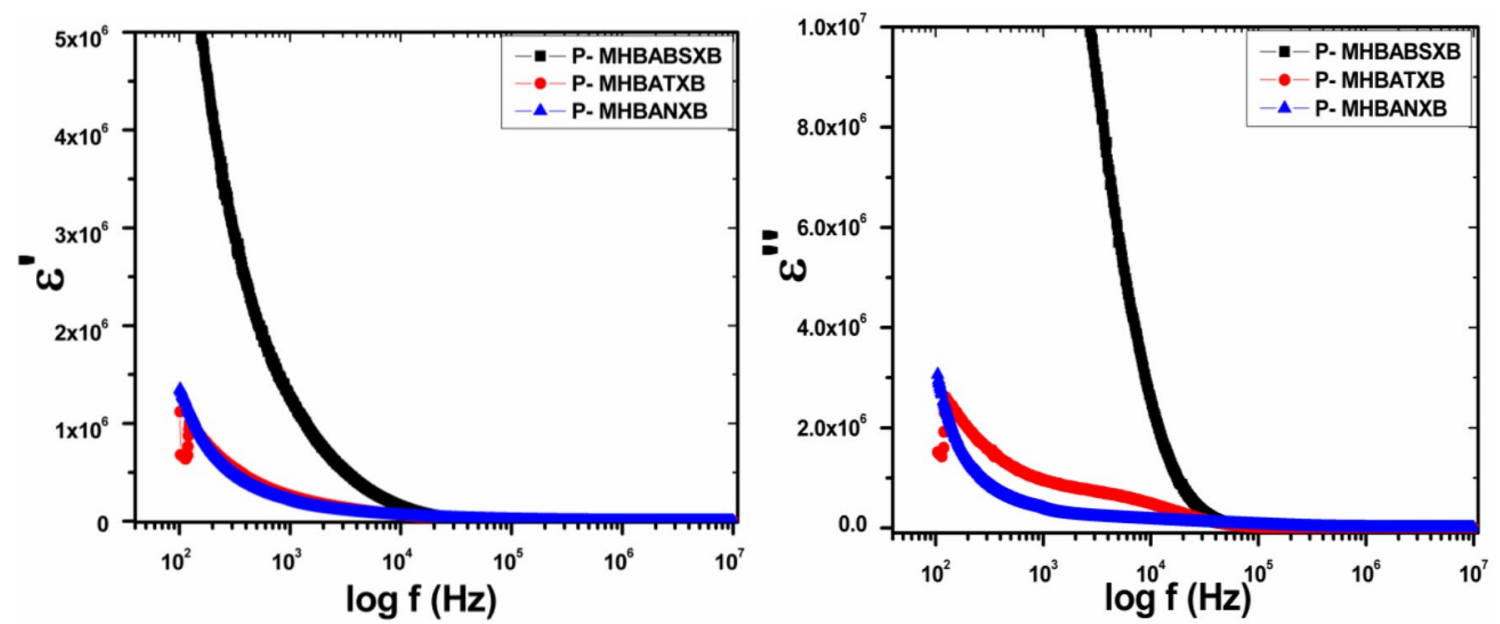

Fig. $7 \varepsilon^{\prime}$ and $\varepsilon^{\prime \prime}$ versus $\log f(\mathrm{~Hz})$ plot for polyazomethines at $30^{\circ} \mathrm{C}$
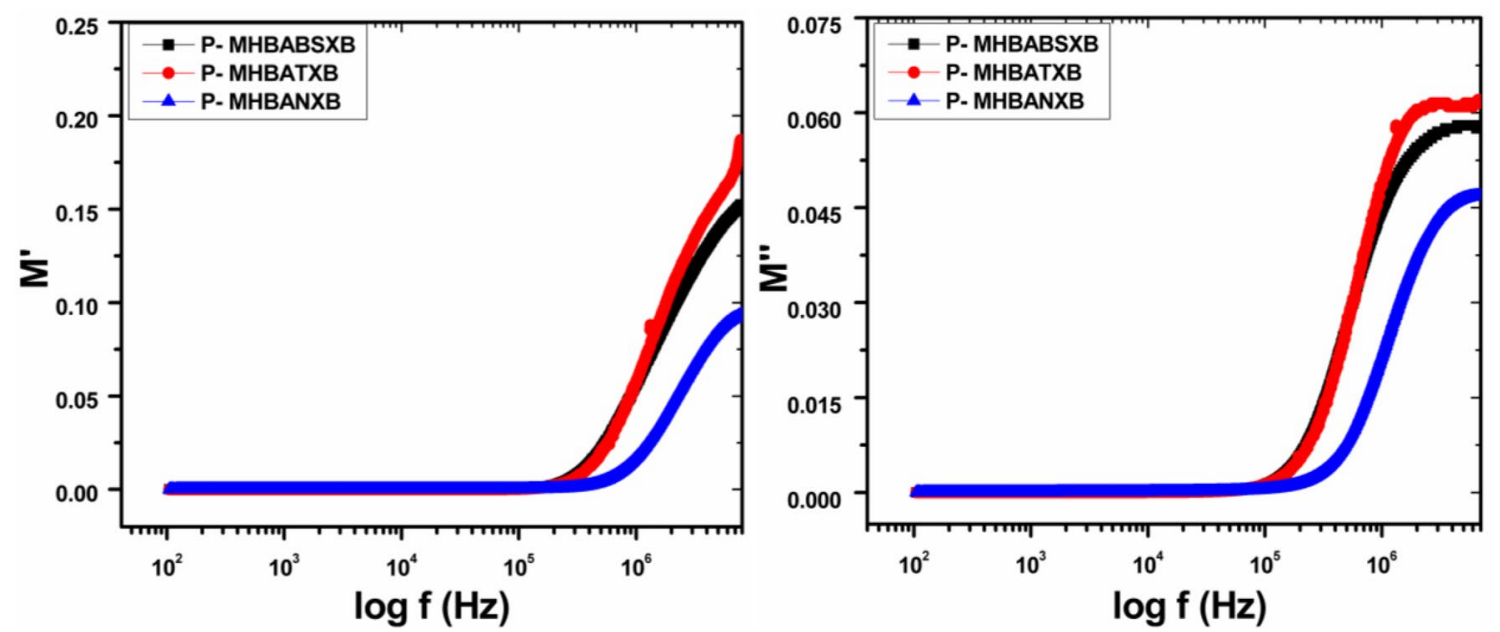

Fig. $8 \mathrm{M}^{\prime}$ and $\mathrm{M}^{\prime \prime}$ versus $\log \mathrm{f}(\mathrm{Hz})$ plot for polyazomethines at $30^{\circ} \mathrm{C}$

where $\varepsilon^{\prime}=$ Real parts of the dielectric constant and $\varepsilon^{\prime \prime}=$ Imaginary parts of the dielectric constant.

From $\tan \delta$ versus $\log f(\mathrm{~Hz})$ graph (Fig. 6b) it is observed that, up to certain value of frequency $\tan \delta$ increases, the frequency where $\tan \delta$ has maximum value is called the dielectric relaxation peak frequency $\left(f_{r}\right)$. With increasing temperature $\mathrm{f}_{r}(\mathrm{~Hz})$ increases (Fig S4), which indicate that the flexibility of polymeric chain increases with increasing temperature.

The complex dielectric permittivity is given as $\varepsilon^{*}=\varepsilon^{\prime}-\mathrm{j} \varepsilon^{\prime \prime} . \varepsilon^{\prime}$ and $\varepsilon^{\prime \prime}$ are associated with the charge capacity and loss of energy by movement of charge respectively. $\varepsilon^{\prime}$ and $\varepsilon^{\prime \prime}$ are given as follows;
$\varepsilon^{\prime}=\frac{C l}{\varepsilon_{o} A} \quad$ and $\quad \varepsilon^{\prime \prime}=\varepsilon_{0} \tan \delta$

where $C=$ capacitance of sample, $\varepsilon_{0}=$ permittivity of free space.

The complex electric modulus study is performed to study the electrode polarization effect and relaxation in polymeric electrolyte systems. The electric modulus given as $\left(M^{*}=M^{\prime}+j M^{\prime \prime}\right)$ is related to complex dielectric permittivity by relation;

$M *=\frac{1}{\varepsilon^{*}}$

$\mathrm{M}^{\prime}$ and $\mathrm{M}^{\prime \prime}$ are calculated by relation; 
Table 4 Electrical conductivity data of polyazomethines

\begin{tabular}{|c|c|c|c|c|c|c|c|c|c|c|c|c|}
\hline \multirow[t]{2}{*}{ Polymer } & \multirow{2}{*}{$\begin{array}{l}\mathrm{R}_{\mathrm{b}} \\
(\mathrm{Ohm})\end{array}$} & \multirow{2}{*}{$\begin{array}{l}\text { DC Conduc- } \\
\text { tivity }(\mathrm{S} / \mathrm{cm})\end{array}$} & \multicolumn{2}{|l|}{$\mathrm{Ea}(\mathrm{eV})$} & \multirow[t]{2}{*}{$\mathrm{N}$} & \multirow[t]{2}{*}{$f_{r}(H z)$} & \multirow[t]{2}{*}{$\varepsilon^{\prime}(\mathrm{F} / \mathrm{m})$} & \multirow[t]{2}{*}{$\varepsilon^{\prime \prime}(\mathrm{F} / \mathrm{m})$} & \multirow[t]{2}{*}{$\mathrm{M}^{\prime}(\mathrm{m} / \mathrm{F})$} & \multirow[t]{2}{*}{$\mathrm{M}^{\prime \prime}(\mathrm{m} / \mathrm{F})$} & \multirow[t]{2}{*}{$C(F)$} & \multirow[t]{2}{*}{$\mathrm{D}$} \\
\hline & & & Before & After & & & & & & & & \\
\hline P-MHBABSXB & 9440 & $4.22 \times 10^{-5}$ & 0.15 & 0.08 & 0.87 & 4236 & $7.1 \times 10^{6}$ & $6.55 \times 10^{7}$ & $4.08 \times 10^{-8}$ & $3.76 \times 10^{-7}$ & $2.79 \times 10^{-6}$ & 10.65 \\
\hline P-MHBATXB & 9472 & $4.23 \times 10^{-5}$ & 0.23 & 0.24 & 0.47 & 7944 & $6.75 \times 10^{5}$ & $1.51 \times 10^{6}$ & $6.2 \times 10^{-6}$ & $1.38 \times 10^{-5}$ & $3.37 \times 10^{-7}$ & 1.77 \\
\hline P-MHBANXB & 3820 & $1.02 \times 10^{-5}$ & 0.09 & 0.05 & 0.14 & 64,362 & $1.32 \times 10^{6}$ & $3.06 \times 10^{6}$ & $1.13 \times 10^{-5}$ & $1.52 \times 10^{-5}$ & $1.19 \times 10^{-7}$ & 2.23 \\
\hline
\end{tabular}

$C$ capacitance, $D$ Dissipation factor

$M^{\prime}=\frac{\varepsilon^{\prime}}{\left(\varepsilon^{\prime 2}+\varepsilon^{\prime \prime 2}\right)} \quad$ and $\quad M^{\prime \prime}=\frac{\varepsilon^{\prime \prime}}{\left(\varepsilon^{\prime 2}+\varepsilon^{\prime \prime 2}\right)}$

where $M^{\prime}=$ Real part of the complex modulus $M^{*}$ and $\mathrm{M}^{\prime \prime}=$ Imaginary part of the complex modulus $\mathrm{M}^{*}$.

Frequency dependent $\varepsilon^{\prime}$ and $\varepsilon^{\prime \prime}$ at different frequencies are shown in Fig. 7 for different polymers at $30^{\circ} \mathrm{C}$. There is sharp increment of $\varepsilon^{\prime}$ and $\varepsilon^{\prime \prime}$ at lower frequency range in plot of dielectric permittivity $\varepsilon^{\prime}$ and $\varepsilon^{\prime \prime}$ versus log $\mathrm{f}(\mathrm{Hz})$ due to electrode polarization. In higher frequency region this polarization effect is suppressed for polymeric films as a result of decrease in fast periodic reversal of electric field [33]. Temperature dependent dielectric permittivity study of polymers confirmed that there is increase in electrode polarization, capacitance of polymeric system and losses energy by displacment of charge with increasing temperature (Figure S5).

In electric modulus $M^{\prime}$ and $M^{\prime \prime}$ versus $\log f(\mathrm{~Hz})$ plot, Fig. 8 shows that large capacitance associated with polymer at lower frequency resulting to a constant line in graph which is approaches to zero. It also indicates the minimum contribution of electrode polarization, the thermally activated relaxation and charge carrier hopping is taking place in polymer system. With increasing temperature $\mathrm{M}^{\prime \prime}$ peak maximum shifted towards higher frequencies (Figure S6) confirms that thermally activated conduction $[34,35]$.

\section{Conclusions}

In this study, three novel $\pi$-conjugated Schiff base type monomers containing syringaldehyde unit were successfully prepared and characterized. Stable and conjugated azomethine polymers soluble in standard organic solvents were synthesized by condensation polymerization. The synthesized conducting polymers were characterized by ${ }^{1} \mathrm{H} N M R$, IR, TGA, GPC, fluorescence, UV-Vis, $C V$ and SEM techniques. The NMR and IR spectroscopic analysis confirmed the formation of Schiff base monomers and their corresponding polymers. Thermal degradation behaviours of the synthesized polymers were also examined. TGA results showed that the synthesized polymers were thermally more stable up to $300{ }^{\circ} \mathrm{C}$. Consequently, due to high thermal stabilities the synthesized polymers may be valuable candidates to produce temperature-stable materials. Polymer synthesis was further confirmed by GPC analysis. The enhance degree of conjugation of polymers was explained by their absorbance and fluorescence spectra that were shifted bathochromically relative to their monomers. According to electrochemical properties, electrochemical band gaps ( $E^{\prime} g$ ) values of the monomer and polymer differ depending on enhance of conjugation. Optical and electrochemical analysis results indicated that polymers possess smaller band gaps than their monomers. The calculated band gaps make the polymers highly suitable for photovoltaic, electronic and optoelectronic applications. The electrical conductivity calculated by iodine doping show good results. Conductivity study showed that the maximum conductivity for all polymers at $100^{\circ} \mathrm{C}$ to be $\sim 10^{-4} \mathrm{~S} / \mathrm{cm}$. The temperature dependent DC conductivity values followed Arrhenius type behavior with low activation energy which confirms the semiconducting nature of polymers. AC conductivity curves followed the Jonscher's Power law with power exponent $n<1$ that support the DC free hopping for all three polymers. Dielectric properties suggested that the dielectric relaxation was thermally activated with charge carrier hopping.

Acknowledgements The authors gratefully acknowledge the financially support from Science Engineering and Research Board (File No. EEQ/2016/000249), New Delhi, Government of India. The authors are grateful to Prof. Biswajit Ray for extending support in GPC analysis and Dr. Pankaj Srivastav for CV analysis of the synthesized polymers.

Funding This study was funded by Science Engineering and Research Board, New Delhi, Government of India. (Grant No. $E E Q / 2016 / 000249$ ).

\section{Compliance with ethical standards}

Conflicts of interests Authors declare there are no conflicts of interests. 


\section{References}

1. Pringle JM, Armel V, MacFarlane DR (2010) Electrodeposited PEDOT-on-plastic cathodes for dye-sensitized solar cells. Chem Commun 46:5367

2. Zhou Q, Shi G (2016) Conducting polymer-based catalysts. J Am Chem Soc 138:2868-2876

3. Mello HJNPD, Mulato M (2018) PANI/PPY blend thin films electrodeposited for use in EGFET sensors. J Appl Polym Sci 135:46625

4. Zhu Y, Li N, Lv T, Yao Y, Peng H, Shi J, Cao S, Chen T (2018) AgDoped PEDOT:PSS/CNT composites for thin-film all-solid-state supercapacitors with a stretchability of $480 \%$. J Mater Chem A 6:941-947

5. Bounioux C, Katz EA, Rozen RY (2012) Conjugated polymerscarbon nanotubes-based functional materials for organic photovoltaics: acritical review. Polym Adv Technol 23:1129-1140

6. Facchetti $A$ (2011) $\pi$-Conjugated polymers for organic electronics and photovoltaic cell applications. Chem Mater 23:733-758

7. Noh HB, Won MS, Hwang J, Kwon NH, Shin SC, Shim YB (2010) Conjugated polymers and an iron complex as electrocatalytic materials for an enzyme-based biofuel cell. Biosens Bioelectron 25:1735-1741

8. Guimard NK, Gomez N, Schmidtb CE (2007) Conducting polymers in biomedical engineering. Prog Polym Sci 32:876-921

9. Kontturi K, Pentti P, Sundholm G (1998) Polypyrrole as a model membrane for drug delivery. J Electroanal Chem 453:231-238

10. Geetha S, Chepuri Rao RK, Vijayan M, Trivedi DC (2006) Biosensing and drug delivery by polypyrrole. Anal Chim Acta 568:119-125

11. Saidi NM, Ng HM, Omar FS, Bashir S, Ramesh K, Ramesh S (2019) Polyacrylonitrile-poly(1-vinyl pyrrolidone-co-vinyl acetate) blend based gel polymer electrolytes incorporated with sodium iodide salt for dye-sensitized solar cell applications. J Appl Polym Sci 136:47810

12. Chan $Y, W u P$ (2015) Semiconducting polymer nanoparticles as fluorescent probes for biological imaging and sensing. Part Part Syst Char 32:11-28

13. Yanagi $H$, Morikawa T, Hotta S, Yase K (2001) Epitaxial growth of thiophene/p-phenylene co-oligomers for highly polarized light-emitting crystals. Adv Mater 13:313-317

14. AISalhi MS, Alam J, Dass LA, Raja M (2011) Recent advances in conjugated polymers for light emitting devices. Int J Mol Sci 12:2036-2054

15. Leclerc M (2001) Polyfluorenes: Twenty years of progress. J Polym Sci Part A Polym Chem 39:2867-2873

16. Yang JS, Swager TM (1998) Porous shape persistent fluorescent polymer films: an approach to tnt sensory materials. J Am Chem Soc 120:5321-5322

17. Zhang LH, Jian T, Wu LB, Wan JH, Chen CH, Pei YB, Lu H, Deng $Y$, Bian GF, Qiu HY, Lai GQ (2012) 2,3,4,5-Tetraphenylsilole-based conjugated polymers: synthesis, optical properties, and as sensors for explosive compounds. Chem Asian J 7:1583-1593

18. Wang Y, Pu KY, Liu B (2010) Anionic conjugated polymer with aptamer-functionalized silica nanoparticle for label-free nakedeye detection of lysozyme in protein mixtures. Langmuir 26:10025-10030

19. Cinarli A, Gurbuz D, Tavman A, Birteksoz AS (2011) Synthesis, spectral characterizations and antimicrobial activity of some
Schiff bases of 4-chloro-2-aminophenol. Bull Chem Soc Ethiop 225:407-417

20. Kumar R (2014) Review on synthesis and application of Schiff base and its transition metal complexes. Res J Chem Environ Sci 2:1-4

21. Hadjoudis E, Mavridis IM (2004) Photochromism and thermochromism of Schiff bases in the solid state: structural aspects. Chem Soc Rev 33:579-588

22. Kaya I, Yıldırım M (2007) Synthesis, characterization, thermal stability, conductivity, and band gap of a new aromatic polyether containing an azomethine as a side. J Appl Polym Sci 106:2282-2289

23. Li XG, Zhou HJ, Huang MR (2005) Synthesis and properties of a functional copolymer from $\mathrm{N}$ ethylaniline and aniline by an emulsion polymerization. Polymer 46:1523-1533

24. Wang C, Shieh S, LeGoff E, Kanatzidis MG (1996) Synthesis and characterization of a new conjugated aromatic poly(azomethine) derivative based on the $3^{\prime}, 4^{\prime}$ dibutyl-aterthiophene building block. Macromolecules 29:3147-3156

25. Senol D, Kaya I (2015) Synthesis and characterization of azomethine polymers containing ether and ester groups. J Saudi Chem Soc 05:006

26. Marin L, Cozan V, Bruma M (2006) Comparative study of new thermotropic polyazomethines. Polym Adv Technol 17:664-672

27. Petrus ML, Bouwer RKM, Lafont U, Murthy DHK, Kist RJP, Bohm ML, Olivier Y, Savenije TJ, Siebbeles LDA, Greenham NC, Dingemans TJ (2013) Conjugated poly(azomethine)s via simple one-step polycondensation chemistry: synthesis, thermal and optoelectronic properties. Polym Chem 4:4182

28. Liou G, Lin H, Hsieh Y, Yang Y (2007) Synthesis and characterization of wholly aromatic poly(azomethine)s containing donoracceptor triphenylamine moieties. J Polym Sci Part A Polym Chem 45:4921-4932

29. Korona KP, Korona T, Rutkowska-Zbik D, Grankowska-Ciechanowicz S, Iwan A, Kamińska M (2015) Polyazomethine as a component of solar cells-theoretical and optical study. J Phys Chem Solids 86:186-193

30. Ye C, Li M, Luo J, Chen L, Tang Z, Pei J, Jiang L, Song Y, Zhu D (2012) Photo-induced amplification of readout contrast in nanoscale data storage. J Mater Chem 22:4299-4305

31. Srivastava N, Kumar M (2016) Ion dynamics and relaxation behavior of NaPF6-doped polymer electrolyte systems. J Solid State Electrochem 20:1421-1428

32. Li W, Pang Y, Liu J, Liu G, Wang Y, Xia Y (2017) A PEO-based gel polymer electrolyte for lithium ion batteries. RSC Adv 7:23494-23501

33. Saroj AL, Singh RK (2012) Thermal, dielectric and conductivity studies on PVA/lonic liquid [EMIM][EtSO4] based polymer electrolytes. J Phys Chem Solids 73:162-168

34. Ramya CS, Selvasekarapandian S, Hirankumar G, Savitha T, Angelo PC (2008) Investigation on dielectric relaxations of PVPNH4SCN polymer electrolyte. J Non-Cyst Solids 354:1494-1502

35. Ladhar A, Arous M, Kaddami H, Raihane M, Lahcini M, Kallel A, Graca MPF, Cost LC (2013) Dielectric relaxation studies on nanocomposites of rubber with nanofibrillated cellulose. J Non-Cyst Solids 378:39-44

Publisher's Note Springer Nature remains neutral with regard to jurisdictional claims in published maps and institutional affiliations. 